\title{
ENZYME LINKED IMMUNOSORBENT ASSAY (ELISA) FOR THE DETECTION OF IgG, IgM, IgE AND IgA AGAINST CYSTICERCUS CELLULOSAE IN CEREBROSPINAL FLUID OF PATIENTS WITH NEUROCYSTICERCOSIS
}

\author{
Newton Satoru Odashima', Osvaldo Massaiti Takayanagui', \\ José Fernando de Castro Figueiredo²
}

\begin{abstract}
The objective of this study was to analyze different immunoglobulins classes ( $\lg \mathrm{G}, \lg \mathrm{M}, \lg \mathrm{E}$ and IgA) against Cysticercus cellulosae in the cerebrospinal fluid (CSF), through enzyme linked immunosorbent assay (ELISA), correlating them to clinical and tomographic profiles in patients with neurocysticercosis (NCC). Eighty-five specimens of CSF were obtained from 43 cases with NCC ( 26 with the active form and 17 with the inactive form) and from 42 patients with other neurological diseases. The inactive form of NCC presented a profile in CSF similar to the group without NCC. The active form of NCC presented elevation of specific immunoglobulins ( $\lg \mathrm{G}, \lg \mathrm{M}, \lg \mathrm{E}$, and $\lg \mathrm{A})$ in decreasing order, with the highest values being detected among the cases with intraventricular cysts, or with inflammation signs in CSF or in those with multiple clinical manifestations. The highest sensitivity and specificity were obtained with ELISA-IgG $(88.5 \%$ and $93.2 \%$, respectively). This study confirmed the importance of ELISA in the immunologic diagnosis of NCC.
\end{abstract}

KEY WORDS: cysticercosis, ELISA, immunologic diagnosis, cerebrospinal fluid.

\begin{abstract}
Reação imunoenzimática para detecção de $\lg G$, $\lg M, \lg E$ e $\lg A$ anticisticerco no líquido cefalorraquiano na neurocisticercose

RESUMO - Este estudo teve como objetivo analisar diferentes classes de imunoglobulinas (lgG, $\lg$ M, $\lg E$ e $\lg A)$ contra Cysticercus cellulosae no líquido cefalorraquiano (LCR), através de ensaio imunoenzimático (ELISA), correlacionando-as com elementos clínicos e tomográficos de pacientes com neurocisticercose (NCC). Foram estudados 85 espécimes de LCR de pacientes, sendo 43 casos com NCC (26 casos com a forma ativa e 17 com a forma inativa) e 42 pacientes portadores de outras doenças neurológicas. A forma inativa de NCC apresentou perfil imunológico no LCR semelhante ao grupo sem NCC. Por outro lado, a forma ativa da NCC apresentou elevação de imunoglobulinas específicas (lgG, $\lg M$, $\lg E$ e $\lg A$ em ordem decrescente), com os maiores valores registrados entre os casos com cistos intraventriculares ou com sinais de inflamação no LCR ou naqueles com manifestações clínicas múltiplas. A máxima sensibilidade e especificidade foi obtida na reação ELISA-lgG $(88,5 \%$ e 93,2\% respectivamente). Este estudo reafirmou o papel do ELISA no diagnóstico imunológico da NCC.
\end{abstract}

PALAVRAS-CHAVE: cisticercose, ELISA, diagnóstico imunológico, líquido cefalorraquidiano.

Neurocysticercosis (NCC) is a major health problem in many regions of the world, mainly in developing countries. It is characterized by a variety of neurological clinical features, some of them very serious in terms of mortality or morbidity ${ }^{1,2}$. Such different expressions of the disease make it even harder to diagnose NCC, so that it becomes practically impossible to confirm the condition without the support of other sources. Within this context, new tech- nologies have led to considerable development over the last two decades. Neuroimaging, first carried out by computed tomography (CT) and later by magnetic resonance (MRI), has greatly contributed to the identification of the disease. At the same time, immunologic methods, especially concerning the study of cerebrospinal fluid (CSF), have been added to the arsenal against the disease. In this context, methods such as enzyme linked immunosorbent assay ${ }^{3}$

Faculty of Medicine of Ribeirão Preto of the University of São Paulo, Ribeirão Preto SP, Brazil; ${ }^{1}$ Department of Neurology, Psychiatry and Medical Psychology; ${ }^{2}$ Division of Tropical and Infectious Diseases, Department of Internal Medicine.

Received 30 November 2001. Accepted 21 January 2002. 
(ELISA) and enzyme immunoelectrotransfer blot ${ }^{4}$ (EITB) are of great importance for the diagnosis of this disease. Enormous progress has also been made during this period in the development of successful techniques and medicines for treatment ${ }^{5,6}$, further emphasizing the need for improvement of diagnosis, particularly in our region, where NCC is endemic.

ELISA was first applied to the identification of human NCC by Arambulo et al. ${ }^{7}$ in 1978, with the detection of $78 \%$ of positive Mexican patients among suspicious ones. Later, Diwan et al. ${ }^{8}$, using the technique described by Voller \& Bidwell ${ }^{3,9}$, analyzed NCC patients in Irian Jaya, Polynesia, and compared their results to those obtained for the Mexican patients. In this study, findings of specific IgG in the serum of $79 \%$ of patients and in the CSF of $80 \%$ of patients increased the enthusiasm for the search of instruments for medical and epidemiological application.

In Brazil, studies by Costa ${ }^{10,11}$ comparing ELISA with other methods of immunodiagnosis of NCC in CSF using different antigen extracts have contributed to the diffusion of the method. This author obtained $100 \%$ sensitivity and $98.5 \%$ specificity using the total saline extract of Cysticercus cellulosae in CSF samples, emphasizing the superiority of this method over complement fixation, immunofluorescence and hemagglutination .

Zini et al. ${ }^{12}$ performed a further analysis between ELISA and the clinical and tomographical features in 1990 after studying NCC patients.

The objective of the present study was to analyze the different classes of immunoglobulins (IgG, $\lg \mathrm{M}, \lg \mathrm{E}$ and $\lg \mathrm{A}$ ) against Cysticercus cellulosae in CSF by ELISA and to correlate the findings with the clinical and tomographic features of the patients.

\section{METHOD}

Patients

During the period between January 1992 and June 1993, 85 cases were selected among the patients referred for investigation to the Cerebrospinal Fluid Laboratory of the University Hospital, Faculty of Medicine of Ribeirão Preto. The medical records of these patients were reviewed taking into consideration: 1) age, gender and origin; 2) anamnesis; 3) cytological and biochemical CSF exams; 4) $\mathrm{CT}$, myelography and cisternography by CT or MRI.

After establishing the diagnostic hypothesis, each patient was assigned to one of the following groups.

Group I $(n=26)$, characterized by the occurrence of active NCC (Sotelo et al. ${ }^{13}$ ), was defined by the following criteria: a. Presence of parenchyma abnormalities detected by CT and/or MRI compatible with the diagnosis of NCC: (a.1) parenchyma cysts in unenhanced $\mathrm{CT}$, with or without enhancement (with a ring or homogeneous aspect) after contrast injection; (a.2) cysts outside the parenchyma, localized in cisternal topography or in the spinal canal, confirmed by cisternography, myelography or surgery; (a.3) nodular calcification in the parenchyma, associated with cysts; (a.4) ventricular enlargement associated with calcification and/or cysts.

b. Abnormalities in CSF: pleocytosis with predominance of mononuclear cells, with or without eosinophil cells, and with or without elevation of CSF protein level. The ELISA IgG and other immunological reactions routinely performed in our laboratory were not considered for purposes of inclusion in this study.

Group II $(n=17)$, characterized by the inactive form of NCC, was defined by the presence of nodular calcification suggesting NCC and the absence of pleocytosis in the CSF.

We adopted in both groups the clinical classification proposed by Trelles \& Lazarte ${ }^{14}$, modified by Takayanagui ${ }^{2}$, consisting of the following categories: epileptic, meningitic, hypertensive, psychic, medullary, cephalalgic, and combined forms.

Group III $(n=42)$, characterized as the group without NCC, was defined by the absence of NCC abnormalities as determined by CT/RMI.

Cases of hydrocephaly of uncertain etiology and cases with doubtful CT/RMI images were excluded from the study.

Procedures

The analytical method employed was the indirect plate immunoenzymatic assay $\left(\right.$ Voller $\left.^{3}\right)$ using the total saline extract as an antigen $\left(\operatorname{Costa}^{10}\right)$. Values of optic density above 0.10 were considered positive.

We search for a correlation between the findings of ELISA reaction to the different immunoglobulin classes and the clinical, tomographic and CSF profiles of patients with the active and inactive forms of NCC.

Data were analyzed statistically by the Kruskal-Wallis test for $\mathrm{n}$ independent samples and by the test for two independent samples (equivalent to the Mann-Whitney $U$ test), with the level of significance set at $p<0.05$.

RESULTS

ELISA IgG

In group I (Table 1) ELISA IgG was positive in 23 cases $(88.5 \%)$, with an average optic density (ODA) of $1.40( \pm 0.76)$. In group II we obtained positive results in two cases (11.8\%), with ODA of 0.10 $( \pm 0.21)$. In group III there were two positive cases $(4.8 \%)$ with ODA of 0.05 ( \pm 0.04$)$.

There were significant differences between groups I, II and III $(p<0.01)$ concerning ODA, which persisted in the paired analysis between groups I and II and groups I and III $(p<0.01)$ but not between groups II and III $(p=0.89)$. 
We observed the occurrence of positive results in 25 of 43 cases with NCC. In group III, 40 cases (95\%) had values below the cutoff. The sensitivity and specificity were $58.1 \%$ and $95.2 \%$, respectively. However, when considering the active forms of NCC, we detected 23 positive cases among the 26 cases with the active form and 55 negative cases among the 59 cases without NCC. Sensitivity and specificity were $88.5 \%$ and $93.2 \%$ (Fig 1 ) respectively.

\section{ELISA IgM}

In group I, ELISA IgM was positive in 17 cases $(65.4 \%)$ with ODA of $0.60( \pm 0.69)$ (Table 1$)$. In group II we obtained no positive results (ODA of 0.05 ). In group III the ODA value was 0.06 , being positive in two cases $(4.8 \%)$.

There was a difference between the 3 groups $(p<0.01)$. However, after the data were submitted to paired analysis for two independent groups, we observed differences between groups I and II $(p<0.01)$, groups I and III ( $p<0.01)$, but not between groups II and III.

We obtained positive results for 17 of the 43 cases with NCC. The sensitivity and specificity obtained were $39.5 \%$ and $95.2 \%$. Considering only the active forms of the disease, we obtained values of $65.4 \%$ and $96.6 \%$, respectively.

\section{ELISA IgE}

In group I, ELISA IgE was positive in 10 cases (31.8\%) with ODA of $0.16( \pm 0.11)$ (Table 1$)$. In group II, only one case was positive (5.9\%), with ODA of 0.07 . In group III there were two positive cases $(4.8 \%)$, with ODA of 0.05 . There was a significant difference between the 3 groups regarding ODA $(p<0.01)$. This difference persisted between groups I and II and between groups I and III, but not between groups II and III.

Sensitivity and specificity were $25.6 \%$ and $95.2 \%$, respectively, for detection of NCC and $38.5 \%$ and $94.9 \%$ for detection of active disease.
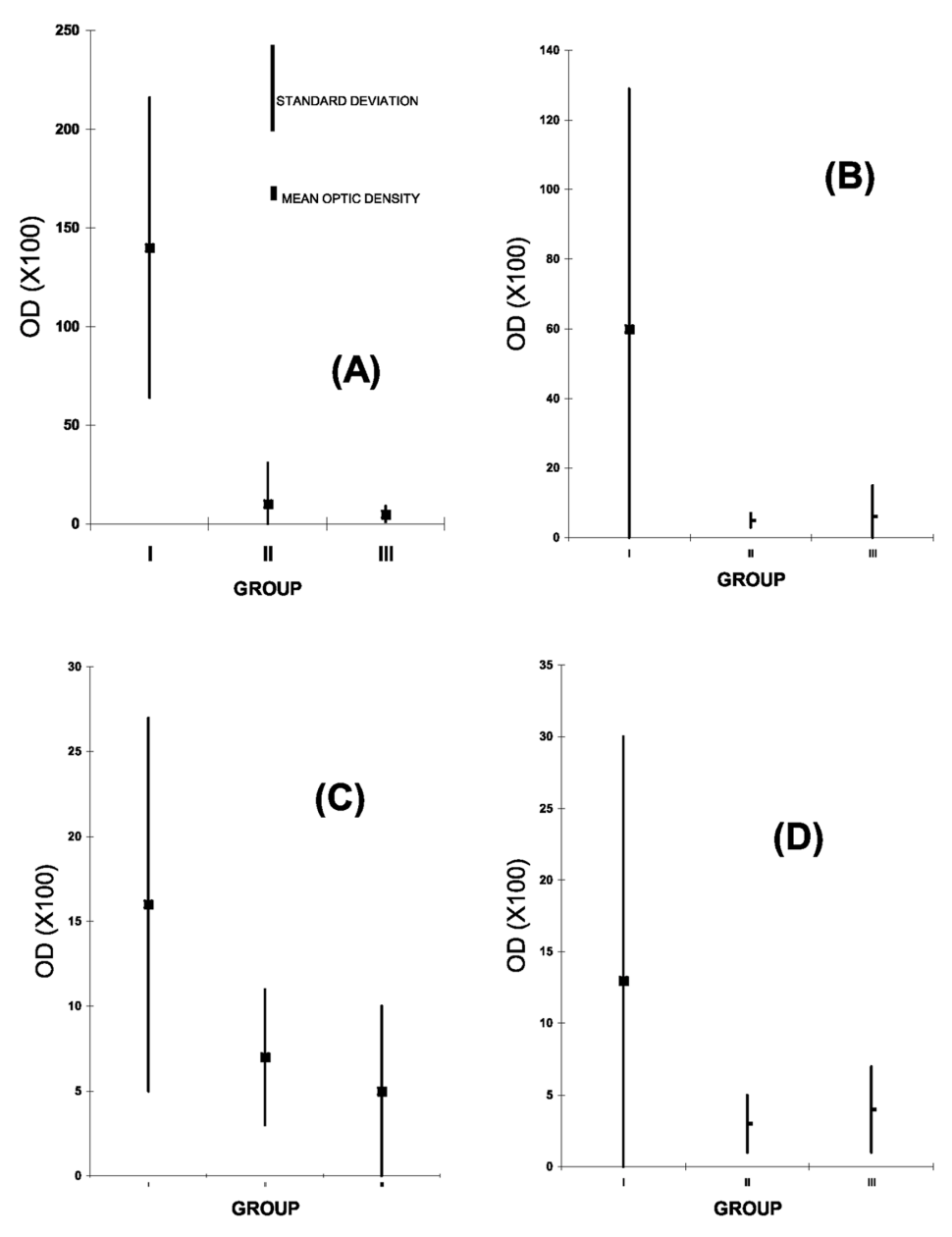

Fig 1. Mean optic density (OD) and standard deviation obtained with ELISA IgG (A), IgM (B), IgE (C) and IgA (D) for groups I, II and III. 
Table 1. Patient distribution according to clinical and tomographic data and to optic density of ELISA reaction in CSF of patients with NCC.

\begin{tabular}{|c|c|c|c|c|c|c|c|c|}
\hline \multirow[t]{3}{*}{ Clinical feature } & \multicolumn{4}{|c|}{ Tomography } & \multirow{2}{*}{\multicolumn{4}{|c|}{$\frac{\text { ELISA }}{\text { Optic density }}$}} \\
\hline & \multirow[t]{2}{*}{ Hydrocephaly } & \multirow[t]{2}{*}{ Calc. } & \multicolumn{2}{|c|}{ Cyst } & & & & \\
\hline & & & Enhanced & Non-henhanced & $\lg G$ & $\lg M$ & $\lg \mathrm{E}$ & $\lg A$ \\
\hline HMAp & + & + & - & - & 2.10 & 2.10 & 0.38 & 0.32 \\
\hline HMEAp & - & + & + & + & 2.10 & 0.39 & 0.40 & 0.12 \\
\hline HME (a) & + & + & - & - & 2.10 & 2.10 & 0.23 & 0.24 \\
\hline HME & + & + & - & - & 2.10 & 0.93 & 0.09 & 0.08 \\
\hline HMMe & + & + & - & - & 1.08 & 0.70 & 0.07 & 0.07 \\
\hline EM & - & + & - & + & 1.13 & 0.39 & 0.08 & 0.09 \\
\hline HM & + & - & - & - & 2.10 & 0.14 & 0.14 & 0.08 \\
\hline ME & + & + & - & - & 2.10 & 2.10 & 0.33 & 0.57 \\
\hline MAp & - & - & + & - & 2.10 & 0.43 & 0.20 & 0.05 \\
\hline ME & - & + & - & - & 1.00 & 0.07 & 0.08 & 0.03 \\
\hline$M$ & + & - & - & - & 2.10 & 0.25 & 0.42 & 0.70 \\
\hline$M^{(a)}$ & - & + & - & - & 2.10 & 0.52 & 0.08 & 0.06 \\
\hline$M$ & - & - & + & & 2.10 & 0.48 & 0.09 & 0.04 \\
\hline$M$ & - & + & + & + & 1.14 & 0.59 & 0.08 & 0.08 \\
\hline$M e^{(b)}$ & & & & & 2.10 & 0.42 & 0.27 & 0.17 \\
\hline $\mathrm{H}$ & + & + & + & - & 1.46 & 0.40 & 0.18 & 0.16 \\
\hline$E$ & - & + & + & - & 2.10 & 2.10 & 0.22 & 0.25 \\
\hline$E$ & + & + & + & - & 1.39 & 0.13 & 0.16 & 0.04 \\
\hline$E$ & - & + & + & + & 1.29 & 0.12 & 0.08 & 0.05 \\
\hline$E$ & - & + & + & - & 0.96 & 0.19 & 0.12 & 0.07 \\
\hline$E$ & - & + & + & + & 0.62 & 0.77 & 0.12 & 0.00 \\
\hline $\mathrm{E}$ & - & + & - & + & 0.49 & 0.05 & 0.07 & 0.03 \\
\hline$E$ & - & + & - & + & 0.47 & 0.14 & 0.10 & 0.03 \\
\hline$E$ & - & - & + & - & 0.06 & 0.06 & 0.06 & 0.05 \\
\hline$E$ & - & - & + & - & 0.02 & 0.04 & 0.06 & 0.03 \\
\hline$C$ & - & + & + & - & 0.06 & 0.07 & 0.06 & 0.08 \\
\hline
\end{tabular}

$\mathrm{H}$, increased intracranial pressure; $\mathrm{E}$, epilepsy; $\mathrm{M}$, meningitis; Ap, apoplexy; $\mathrm{C}$; headache; Me, spinal form; $\mathrm{P}$, psychic; Calc, nodular calcification; (+), present; (-), absent; (a), cyst in cisterna; (b), tomography not done.

\section{ELISA IgA}

In group I, ELISA IgA was positive in 7 cases (26.9\%) with ODA of $0.13( \pm 0.17)$ (Table 1). In group II we found no positive cases, with ODA of 0.03 , and in group III we detected only one positive case $(2.4 \%)$, with ODA of 0.04 .

There was a difference between the 3 groups concerning ODA $(p<0.01)$. Paired analysis showed a difference between groups I and II and II and III, but not between groups II and III.

Sensitivity and specificity were $16.3 \%$ and $97.6 \%$, respectively, for the detection of NCC, and $26.9 \%$ and $98.3 \%$, for the detection of active disease.

\section{ELISA and clinical-tomographic correlations}

CT showed important differences between the ODA for the four immunoglobulins and the presence or absence of ventricular enlargement (Table 2 ), but this was not the case for the evolutive stage of the larvae (cyst with or without enhancement). Similarly, we obtained no correlation with total number of cysts.

There were significant differences in terms of the presence of inflammatory signs in CSF and the values of ODA among the four immunoglobulin classes (Table 3).

The analysis of each individual syndrome revealed 
Table 2. Mean optic density (ODA) and standard deviation in the ELISA test for IgG, IgM, IgE and IgA in CSF, according to tomographic findings in patients with NCC.

\begin{tabular}{cccc}
\hline & \multicolumn{2}{c}{ Tomography $(\mathrm{n}=25)$} & \\
\cline { 2 - 3 } ELISA & cysts & hydrocephaly & $\mathrm{p}$ \\
& $\mathrm{n}=16$ & $\mathrm{n}=9$ & \\
\hline $\lg \mathrm{g}$ & $1.10 \pm 0.79$ & $1.84 \pm 0.41$ & 0.02 \\
$\lg \mathrm{M}$ & $0.40 \pm 0.51$ & $0.98 \pm 0.88$ & 0.05 \\
$\lg \mathrm{E}$ & $0.12 \pm 0.09$ & $0.22 \pm 0.13$ & 0.02 \\
$\lg \mathrm{A}$ & $0.07 \pm 0.06$ & $0.25 \pm 0.24$ & $<0.01$ \\
\hline
\end{tabular}

$\mathrm{p}$, statistical significance level.

Table 3. Average optic density values in ELISA IgG, IgM, IgE and IgA in CSF, according to CSF characteristics in patients with NCC.

\begin{tabular}{lccc}
\hline \multirow{2}{*}{ ELISA } & \multicolumn{3}{c}{ CSF } \\
\cline { 2 - 3 } & Normal & Abnormal & $\mathrm{p}$ \\
& $\mathrm{n}=14$ & $\mathrm{n}=12$ & \\
\hline DOIgG & 1.06 & 1.79 & 0.02 \\
DOIgM & 0.36 & 0.88 & 0.01 \\
DOIgE & 0.12 & 0.21 & $\mathrm{~ns}$ \\
DOIgA & 0.07 & 0.21 & 0.03 \\
\hline
\end{tabular}

p, statistical significance level.

Table 4. Average optic density for ELISA IgG, IgM, IgE and IgA in CSF, according to clinical profile of NCC.

\begin{tabular}{lccc}
\hline & \multicolumn{2}{c}{ Clinical Profile } & \\
\cline { 2 - 3 } ELISA & Single & Combined & $\mathrm{p}$ \\
& $\mathrm{n}=16$ & $\mathrm{n}=10$ & \\
\hline DOIgG & $1.15 \pm 0.80$ & $1.79 \pm 0.50$ & 0.05 \\
DOIgM & $0.40 \pm 0.51$ & $0.94 \pm 0.84$ & $\mathrm{~ns}$ \\
DOIgE & $0.14 \pm 0.10$ & $0.20 \pm 0.13$ & $\mathrm{~ns}$ \\
DOIgA & $0.12 \pm 0.17$ & $0.16 \pm 0.17$ & $\mathrm{~ns}$ \\
\hline
\end{tabular}

p, statistical significance level.

the following quantitative determinations of IgG ODA: apopleptic form (2.1), meningitis (1.95), hypertensive (1.86), spinal (1.59), epileptic (1.19) and cephalalgic (0.06). When we compared cases with combined syndromes $(n=10)$ and cases with a single syndrome $(n=16)$, we found that the ODA varied significantly with number of syndromes (Table 4).

\section{DISCUSSION}

In patients with NCC, Flisser et al. ${ }^{15}$ detected the involvement of the main immunoglobulin classes
( $\lg G, \lg \mathrm{M}, \lg \mathrm{E}, \lg \mathrm{A}$ and $\lg \mathrm{D}$ in decreasing order) in serum while Bueno et al ${ }^{16}$ detected the occurrence of IgG, IgA and IgE in CSF. The antigenic determinants of this response show marked heterogeneity. Grogl et al. ${ }^{17}$ determined that the serum of patients with NCC could identify more than 30 parasitic antigens of $C$. cellullosae. The antigens, polypeptides whose molecular weight ranges from 16 to $200 \mathrm{kDa}$, sometimes react with just one class of immunoglobulins ( $\lg G, \lg M, \lg E$ or less frequently $\lg A$ ), while others are identified by more than one class in a nonspecific manner.

The exact mechanism of the humoral response to parasites is unknown. Correa et al. ${ }^{18}$ studied the presence of antibodies on the wall of cysticerci extracted from many parts of the body (from the eye, subcutaneous tissue and brain parenchyma), and identified the presence of $\lg G, \lg M, \lg A$ and $\lg E$ and complement fraction of (C3b). However, they could not find any correlation between the presence of these elements and intrinsic lesions to the wall of the larvae.

In our material we detected the presence of high levels of specific immunoglobulins in the group with an active form of NCC, with higher IgG positivity, followed, in decreasing order, by positivity to IgM, $\lg \mathrm{E}$ and $\lg \mathrm{A}$, in agreement with data reported by others about the higher participation of IgG in the immune response to NCC ${ }^{16,19}$.

The $88.5 \%$ sensitivity and $93.2 \%$ specificity obtained here for ELISA IgG agree with values reported in the literature. Furthermore, the value obtained with ELISA IgM was close to that obtained by Michault et al. ${ }^{20}$, although we could not reproduce the value obtained by Rosas et al. ${ }^{21}$, who reported $87 \%$ sensitivity for ELISA IgM.

The occurrence of positive reactions in group II could be ascribed to an immunological scar of NCC or to the limitations of the tomographic method (used as the gold standard in this study) in the detection of small cysticerci, perhaps located inside the ventricular system, or of dead larvae in the pseudonormal tomographic phase. Machado et al. ${ }^{22}$ reported a gap of 14 months between the early signs of degeneration of the cysts and the visualization of calcifications.

The immunoglobulin levels depend on the localization of the cysts in the central nervous system (CNS). The closer the cysts are to the ventricular system, the higher the antibody content tends to be ${ }^{23}$. These mechanisms may have been active in three of 
the cases, two of them with frontal cysts and the other one with temporal lesion. Another factor possibly involved is the number of lesions. The presence of solitary cysts is related to lower sensitivity of the immunodignostic methods.

The presence of cysticerci in the CNS determines immunological changes in the CSF in a multifactorial way. In this study we verified that the immunological response tended to be more intense in the active disease, mainly in cases with intraventricular lesions, with CSF signs of inflammation and in cases with multiple clinical syndromes. We could not correlate any particular immunoenzymatic assay (lgG, $\lg \mathrm{M}, \lg \mathrm{E}$ or $\lg \mathrm{A})$ with a specific evolutionary stage of the larvae. We observed cases with only one cyst with higher immunoglobulin levels than cases with dozens of lesions, eventually reflecting the influence of intrinsic factors of the host or of the location of the lesion.

In spite of the development of image technology, the changes observed in the CSF have a pivotal role in the diagnosis of NCC. In addition to these alterations, expressed by the "cerebrospinal fluid syndrome" of Lange ${ }^{24}$, we observed others of an immunological nature. The diffusion of ELISA as well as the development and refinement of other technologies will result in a more refined diagnosis of NCC.

\section{CONCLUSIONS}

In NCC there are immunological changes detectable in the CSF by the immunoenzymatic technique, characterized by elevation of specific antibodies of the $\lg G, \lg M, \lg E$ and $\lg A$ classes $^{25}$. The changes observed differ for the various immunoglobulin classes, with elevations of $\lg G, \lg \mathrm{M}, \lg \mathrm{E}$ and $\lg \mathrm{A}$ being observed in decreasing order of magnitude. The highest potential for the detection of active NCC was obtained with ELISA IgG $(88.5 \%$ sensitivity and $93.2 \%$ specificity). The immunological changes observed in CSF occur preferentially in the active forms. In these cases the immunoglobulin content is heterogeneous and related to multiple factors involving the localization of the parasite, the inflammation of CSF and the multiplicity of clinical symptoms. We did not obtain a correlation between evolutionary stage of the disease and changes in IgG, IgM, $\lg \mathrm{E}$ and $\lg \mathrm{A}$ profiles. Moreover, the number of parasites observed in the active forms was not correlated with the optic density obtained with ELISA IgG, IgM, $\lg E$ and $\lg A$.

\section{REFERENCES}

1. Sotelo J, Marin C. Hydrocephalus secondary to cysticercotic arachnoiditis: a long-term follow-up review of 92 cases. J Neurosurg 1987; 66: 686-689.

2. Takayanagui OM. Neurocisticercose: I. Evolução clinico-laboratorial de 151 casos. Arq Neuropsiquiatr 1990;48: 1-10.

3. Voller A, Bidwell DE, Bartlett A. Enzyme immunoassays in the diagnostic medicine. Bull WHO 1976; 53: 55-65.

4. Tsang VC, Brand JA, Boyer AE. An enzyme-linked immunoelectrotransfer blot assay and glycoprotein antigens for diagnosing human cysticercosis (Taenia solium). J Infect Dis 1989;159:50-59.

5. Sotelo J, Escobedo F, Penagos P. Albendazole vs praziquantel for therapy for neurocysticercosis: a controlled trial. Arch Neurol 1988; 45: 532-534.

6. Takayanagui OM, Jardim E. Therapy for neurocysticercosis - comparison between albendazole and praziquantel. Arch Neurol 1992; 49: 290294.

7. Arambulo PV, Walls KW, Bullock S, Kagan IG. Serodiagnosis of human cysticercosis by microplate enzyme-linked immunospecific assay (ELISA). Acta Trop (Basel)1978; 35: 63-67.

8. Diwan AR, Coker-Vann M, Brown P, et al. Enzyme-linked immunosorbent assay (ELISA) for the detection of antibody to cysticerci of Taenia solium. Am J Trop Med Hyg 1982; 31: 364-369.

9. Bidwell DE, Buck AA, Diesfend HJ. The enzyme-linked immunosorbent assay (ELISA). Bull Who 1976;54:129-139.

10. Costa JM, Ferreira AW, Makino MM, Camargo ME. Spinal fluid immunoenzymatic assay (ELISA) for neurocysticercosis. Rev Inst Med Trop São Paulo. 1982;24:337-341.

11. Costa JM. Teste imunoenzimático (ELISA) no diagnóstico da neurocisticercose: estudo de diferentes extratos antigênicos na detecção de anticorpos IgG em amostras de soro e de líquido cefalorraqueano. Arq Neuropsiquiatr 1986;44:15-31.

12. Zini D, Farrell VJ, Wadee AA. The relationship of antibody levels to the clinical spectrum of human neurocysticercosis. J Neurol Neurosurg Psychiatry 1990; 53:656-661.

13. Sotelo J, Guerrero V , Rubio F. Neurocysticercosis: a new classification based on active and inactive forms. Arch Intern Med 1985;145:442-445.

14. Trelles JO, Lazarte J. Cisticercosis cerebral: estudio clínico, histopatológico y parasitológico. Rev Neuropsiquiatr (Lima) 1940;3:393-511.

15. Flisser A, Woodhouse E, Larralde C. Human cysticercosis: antigens, antibodies and non-responders. Clin Exp Immunol 1980;39:27-37.

16. Bueno EC, Vaz AJ, Machado LR, Livramento JA. Neurocysticercosis: detection of IgG, IgA and IgE antibodies in cerebrospinal fluid, serum and saliva samples by ELISA with Taenia solium and Taenia crassiceps antigens. Arq Neuropsiquiatr 2000;58:18-24.

17. Grogl M, Estrada JJ, MacDonald G, Kuhn RE. Antigen-antibody analyses in neurocysticercosis. J Parasitol 1985;71:433-442.

18. Correa D, Dalma D, Espinoza B, et al. Heterogeneity of humoral immune components in human cysticercosis. J Parasitol 1985; 71: 535-541.

19. Mohammad IN, Heiner DC, Miller BL, Goldberg MA, Kagan G. Enzyme-linked immunosorbent assay for the diagnosis of cerebral cysticercosis. J Clin Microbiol 1984; 20: 775-779.

20. Michault A, Leroy D, Coubes P, Laporte JP, Bertil G, Mignard C. Diagnostic immunologique dans le liquide cephalo-rachidien et le serum de la cysticercose encephalique evolutive. Pathol Biol (Paris) 1989; 37:249-253.

21. Rosas N, Sotelo J, Nieto D. ELISA in the diagnosis of neurocysticercosis. Arch Neurol 1986;43:353-356.

22. Machado LR, Nobrega JP, Barros NG, Livramento JA, Bacheschi LA, Spina-Franca A. Computed tomography in neurocysticercosis: a 10year long evolution analysis of 100 patients with an appraisal of a new classification. Arq Neuropsiquiatr 1990;48:414-418.

23. Machado LR. Neurocisticercose: exame do líquido cefalorraqueano. In Machado LR, Livramento JA, Spina-França Netto A, Nóbrega JPS (eds) Neuroinfecção 96. São Paulo: Clínica Neurológica HC/FMUSP, 1996:203212.

24. Lange O. Síndromo liquórico da cisticercose encéfalo-meningéia. Rev de Neurol Psiquiatr São Paulo 1940;6(2):35-48.

25. Odashima NS. Reação imunoenzimatica para deteç̧ão de IgG, IgM, IgE, e IgA anticisticerco no líquido cefalorraquiano na neurocisticercose. Tese, Universidade de São Paulo. Ribeirão Preto, 1997. 